\title{
Bir Siyasal İletişim Aracı Olarak Yeni Medya: 2017 Halkoylamasında AK Parti YouTube Videoları Üzerine Göstergebilimsel Bir Çalışma*
}

\section{New Media as A Political Communication Tool: A Semiotic Study on AK Party's YouTube Videos in 2017 Referendum}

\author{
Salih Gürbüz ${ }^{\mathrm{a}, * *}$ \\ ${ }^{a}$ Dr. Öğr. Üyesi, Necmettin Erbakan Üniversitesi, Güzel Sanatlar Fakültesi, Sinema Televizyon Bölümü, 42040, Konya/Türkiye. \\ ORCID: 0000-0002-5690-8136
}

\section{MAKALE BİLGİṠ \\ Makale Geçmişi: \\ Başvuru tarihi: 18 Mayıs 2018 \\ Düzeltme tarihi: 16 Haziran 2018 \\ Kabul tarihi: 18 Temmuz 2018}

\section{Anahtar Kelimeler:}

Yeni Medya

Siyasal İletişim

Göstergebilim

Ak Parti

YouTube

\section{ARTICLE INFO}

\section{Article history:}

Received May 18, 2018

Received in revised form June 16, 2018 Accepted July 18, 2018

\section{Keywords:}

New Media

Political Communication

Semiotic

Ak Parti

YouTube
ÖZ

Bu çalışmada Türkiye'de 2017 Nisan ayında yapılan referandum sürecinde AK Parti'nin YouTube üzerinde kendi kurumsal hesabında paylaştığı "Tüm Kalbimle Evet” isimli 13 video göstergebilim yöntemi ile incelenmiştir. İncelenen videolarda kadın, erkek hemen her yaştan ve farklı mesleklerden, farklı şehirlerden vatandaşın yer aldığı ve milli, manevi, yerel, eğitim, ekonomik ve toplumsal cinsiyet bağlamında göstergelere yer verildiği değerlendirilmiştir. Böylece AK Parti'nin her yaştan, her meslek grubundan kadın ve erkek seçmenine ulaşmak istediği ve ülkenin milli, manevi değerlerine bağlı bir parti olduğunu ve ülke ekonomisinin daha iyi olmasını referandumla ilişkilendirdiği, yerel nitelikli görseller ile ülkenin tüm şehirlerindeki seçmeni ayrı ayrı önemsediği, yükseköğrenimin parti için önemli bir politika olduğu, kadın seçmenin parti için değerli olduğu mesajlarının verilmek istendiği değerlendirilmiştir.

\section{Giriş}

İletişimin günümüzde geldiği nokta, insanın ihtiyaçlarına göre dili ve dilin unsurlarını şekillendirdiğini rahatlıkla göstermektedir. Özellikle dijitalleşmenin, her alanda olduğu gibi iletişim alanında da hızlı bir şekilde yer edinmesi, iletişimin çeşitliliğini artırmaktadır. Bu çeşitlilik en çok da internetin olanaklarından yararlanan yeni medya araçlarında kendini göstermektedir. Önceleri yazıyı temele alan yeni medya iletişimi, sonraları görsel ve işitsel unsurları da bir araya getiren ortamlara dönüşmüştür. Böylece bireyler kendini tanıtma, ifade etme, beğenilme, onaylanma, çevre edinme, arkadaş çevresini genişletme gibi ihtiyaçlarını, yeni medyanın sunduğu olanaklarla ürettikleri iletilerle karşılama yolunu seçmektedirler. Bireylerin iletişime yönelik değişen bakış açısı, siyaset kurumunun da öncelediği ve dikkate

\footnotetext{
* Bu çalışma, 25-28 Nisan 2018 tarihlerinde Eskişehir'de düzenlenen 16th International Symposium Communication in the Millennium isimli sempozyumda bildiri olarak sunulmuştur.

** Sorumlu yazar/Corresponding author.

e-posta: gurbuzsalih@ hotmail.com
} 
almak mecburiyetinde kaldığı bir içerik üretme yarışını da beraberinde getirmiştir. Son yıllardaki seçim kampanyalarında ortaya konan, özellikle internet aracılığıyla üretilen içeriklerde bu iletişim kaygısının siyasete de yansıdığı rahatlıkla gözlenebilmektedir. Yeni medyanın sunduğu çeşitli olanaklar ise siyaset yapan kurumların da seçmeniyle olan iletişimine yeni firsatlar sağlamaktadır. Görselliğin insanlar için fazlasıyla değer bulduğu günümüz dünyasının farkında olan siyasi kurumlar, görsel ve işitsel mesajların bir arada etkili sunulduğu siyasal iletişim içerikli ürünler üreterek seçmenlerini etkilemek için çaba göstermektedir. Partilerin bu çabalarıyla ürettikleri siyasal iletișim içerikli ürünleri, geleneksel medya araçlarında paylaşıldığı gibi partilerin kurumsal yeni medya hesapları üzerinden de seçmen kitleyle paylaşılmaktadır. Özellikle yeni medyanın kalıcılık, ulaşılabilirlik, erişim ve kullanım kolaylığı gibi özellikleri sayesinde, seçmen kitle paylaşılan bu içeriklere kolayca ulaşarak istediği tekrarda bu videoları izleyebilmektedir. Bu durum partilerin vermek istedikleri mesajların etkisine olumlu katkı sağlamaktadır. Bu sebeple çalışma kapsamında değerlendirilecek olan siyasal iletişim içerikli videolarla AK Partinin seçmenine vermek istediği mesajlarda hangi hususları öncelediği araştırılmıştır.

\section{Siyasal İletişim}

İletişim "anlamların simgeler aracılı̆̆ıla karşılıklı paylaşıldığı bir süreç” olarak tanımlanmaktadır. İletişimin gerçekleşmesi ise kaynak, ileti, kanal/araç ve hedef öğelerinin varlığına bağlıdır. Bu öğelerden birinin eksikliği iletişimin gerçekleşmesini engellemektedir (Gökçe, 2013: 41). Bu durum siyasal iletişim için de geçerlidir. Siyasilerin ve siyasi partilerin kaynak olduğu siyasal iletişim sürecinde, üretilen her mesaj ve içerik ileti olarak değerlendirilebilirken, bu süreçte görev alan kaynak ya da araçlar ise genellikle kitle iletişim araçları ve son yıllarda ise yeni medya araçları olmaktadır. Hedef kitle ise ikna edilecek ve etkilenecek olan seçmen kitlesidir. Siyasal iletişim ile ilgili birçok tanımda ikna ve etki kavramlarının kullanıldığ ifade edilmektedir (K1lıç, 2013: 48). Ancak hem "siyasal" hem de "iletişim" kavramlarının geniş kapsamlı olmaları sebebiyle siyasal iletişim hakkında tek bir tanımın yapılması oldukça güçtür. Fakat Aziz (2011: 3) siyasal iletişim kavramını: "Siyasal aktörlerin belli ideolojik amaçlarını, belli gruplara, kitlelere, ülkelere ya da bloklara kabul ettirmek ve gerektiğinde eyleme dönüşürmek, uygulamaya koymak üzere çeşitli iletişim tür ve tekniklerini kullanmaları" şeklinde yalın bir halde tanımlamaktadır.

McNair (2003: 4) ise siyasal iletişimde mesajın içeriğine ve amacına dikkat çekmektedir. Bu sebeple siyasal iletişimi ifade ederken, "siyaset üzerine amaçlı bir iletişim" tanımını ortaya koymaktadır. Bu siyasal iletişim tanımı kapsamında olanları ise şu şekilde sıralamaktadır.

(i) Özel hedeflere ulaşmak amaciyla siyasetçiler ve diğer politik aktörler tarafından üstlenilen tüm iletişim biçimleri.

(ii) Siyasi aktörlere yönelik olarak seçmenler ve gazete köşe yazarları gibi siyasi olmayanlar tarafından yapılan iletişim.

(iii) Siyasi aktörler ve onların çalışmaları hakkında haber raporlarında, başmakalelerde ve diğer siyasi tartışmaların olduğu medya ortamlarında yer alan iletişim.

Böylece siyasal iletişim siyasi kişi ve kurumlarca, seçmenlerce ve çeşitli medya organlarınca gerçekleştirilen amaçlı bir iletişim olarak ifade edilebilir.

\subsection{Medya ve Siyasal İletişim}

Kitle iletişimi üzerine yapılan ilk araştırmalarda toplumun işleyişinde kitle iletişiminin hayatiyeti üzerine odaklanılmıştır. Berelson, Lazarsfeld, Hovland ve çağdaşlarının çalışmalarına bakıldığında, siyasal kampanyaların ve propagandanın insanlar üzerindeki etkilerini araştırmaya yönelik olduğu görülmektedir. Tüm bu çalıșmaların ve diğerlerinin ortak noktası medyanın insanları, fikirleri ve malları satmak amaciyla nasıl kullanılabileceği üzerineydi (Ruddock, 2001: 81-82). Günümüzde çok çeşitli tanıtım ve pazarlama yöntemlerinin uygulanabilmesine olanak tanıyan yeni medya ortamlarında üretilen içerikler siyasal kampanya ve propaganda amaçlı olarak da kullanılmaktadır. Bu noktada yeni medya ortamlarında partiler ya da siyasilerin hedef kitleye bir nevi arzını ya da pazarlamasını yapmak adına yeni medyanın önemli kitle iletişim araçları arasında sayılmaya başlandığı ifade edilebilir.

Medyanın siyaset üzerindeki etkisine yönelik daha önceki çalışmalar, siyasal gazeteciliğin eşik bekçiliği ve gündem belirleme işlevlerine ve medya etkileri üzerine odaklanmıştır (Lengauer vd., 2013). Bu noktada McCombs ve Shaw'1n belirttiği gibi kitlelerin ne hakkında düşüneceğini belirlemede medyanın önemli bir rolü olduğu bilinmektedir Ancak yeni medya ile medyanın gündem belirlemesi farklı bir boyut kazanmıştır. Günümüzde yeni medya ortamlarının sunduğu imkânlar sayesinde, bireyler ve kurumlar gibi partiler ve siyasal aktörler sahip oldukları yeni medya hesapları üzerinden kitleleri kendileri hakkında bilgilendirmek, kitleler üzerinde izlenim oluşturmak ve algıları şekillendirmek amacıyla kendi ürettikleri içeriklerle paylaşımlar yapabilmektedir. Yeni medyanın bu özelliğinin siyasi aktörler ve partilere, geleneksel medya organlarının siyasi adaylara ve partilere yönelik olarak uyguladıkları filtrelemeler ve gündem belirleme gücüne karşı kısmen bir özgürlük ve seçmenle doğrudan iletişim kurabilme imkânı kazandırdığı ifade edilebilir. Ancak burada dikkat edilmesi gereken önemli bir husus, partinin ya da adayın kendi mesajını doğrudan hedef kitleye ulaştırırken paylaşılan içerikte yer alacak hususların nelere dikkat edilerek belirlendiğidir. Paylaşılan içerikteki küçük bir hatanın ciddi krizlere sebep olabileceği ihtimalinden dolayı, yeni medyada hedef kitleyle kurulacak iletişimde paylaşılacak mesajın çeşitli boyutlarında üretim, tasarım ve paylaşımından sorumlu uzman bir ekibin varlığı gerekli olmaktadır. Bu gereklilik, siyasal iletişim yönetiminin sosyal medya boyutu olarak ifade edilebilir.

Bu noktada Weimann ve Brosius'un (2016: 28), YouTube, Facebook ve Twitter gibi çoğu sosyal medya ortamının hızlı olma özellikleri sayesinde, geleneksel haber kaynaklarının gündemini etkileyebilecek yeterlilikte olduğunu belirten ifadeleri doğrultusunda düşünüldüğünde, etkili kullanılan bir yeni medyanın siyasal iletişimde oldukça önemli bir araç olabileceği ifade edilebilir. 
Seçmenler karar vermek için "siyasal bilgiye" gereksinim duymaktadır. Seçmenin algısını şekillendirirken siyasi partiler, adaylar, parti programları, vaatler vb. bilgiler önemli bir değere sahiptir. Seçmenin gerek duyduğu tüm bilgilerin belirli bir yöntem ve kapsam çerçevesinde seçmenlere aktarılması, siyasal iletişim yönetiminin temel görevleri arasındadır. Seçim kampanyalarının planlanması, siyasal reklamlar, halkla ilişkiler, medya yönetimi, iletişim stratejileri vb. birçok öğe siyasal iletişim yönetimi arasında ifade edilmektedir. Tüm bunlar ise seçmenin özgür kanaatini ve kararlarının şekillenmesine destek olmaktadır (Özkan, 2015: 7). Bu noktada sosyal medya ortamlarında da hassas bir siyasal iletişim yönetiminin gerekliliği söz konusu olmaktadır.

Rawnsley (2005: 177) ise internetin ve internet araçlarının siyasal iletişimde kullanıldığında demokratikleşmeye katkı sağlayacağına yönelik düşüncesini, Rheingold'ın “'Internetin doğru anlaşılıp, kullanıldığında ve yeteri kadar hedef kitle tarafından iyi şekilde bilindiğinde diğer medya araçları ile aynı demokratikleşme potansiyeline sahip olabileceği" görüşünü paylaşarak ifade etmektedir.

Siyasal kurumlar ve siyasiler günümüzde sadece seçim dönemlerinde değil, seçim dışı zamanlarda da hem yeni seçmenler kazanmak hem de mevcut seçmenini korumak ve desteğini devam ettirmek için geleneksel medyada sürekli olarak varlık göstermektedir. Yeni medyanın seçmenin günlük kullanım alışkanlıkları arasında yer almasıyla, siyasiler bu yeni medya ortamını da kullanmaya başlamıştır. Böylece yeni medya siyasilerin seçmeniyle iletişime geçtiği yeni bir iletişim ortamı olmakla birlikte, siyasilere seçmenin beklenti ve isteklerinden haberdar olma firsatını da sunmaktadir.

Yeni medya ortamlarında firsatlarla birlikte tehditler de gelişebilir. Yeni medyanın bir kurgu aracı olarak kullanılabilmesi sayesinde, siyasi kişi ve kurumlar hakkında paylaşılan içerikler olumlu ya da olumsuz imajın oluşmasına da sebep olabilir (Gürbüz ve Aydın, 2017: 538). Bu nedenle hem siyasiler hem de siyasi partiler yeni medya hesapları üzerinden olumlu imaj oluşturmak amacıyla paylaşımlarda bulunurlar. Seçmene iletilecek mesajın etkisi ise mesajın sunumu ile doğrudan ilişkilidir. Bu etki ise görsel ve işitsel mesajların birlikte sunulduğu yeni medya ortamlarında kolayca gerçekleşebilmektedir. Özellikle YouTube seçmenlerle iletişim kurmak için tercih edilen yeni medya ortamları arasında önemli görülmektedir.

\subsection{Teknoloji ve Siyasal İletişim}

Siyasal iletişimde her ne kadar hala partilerin ve liderlerin meydan mitinglerinde seçmenle buluşmaları söylevin etkisinin devam ettiğini gösterse, tek başına yetersiz kalmaktadır. Bu sebeple siyasi partiler medyanın, özellikle yeni medyanın sunduğu firsatlarından yararlanarak siyasal iletişim bağlamında içerikler geliştirmektedir. Teknolojinin firsatlarıyla her geçen gün biçimsel yenilikler kazanan yeni medyada siyasal iletişime yönelik üretilecek ürünlerde zenginleşmektedir. Görsel, işitsel ve yazılı kaynakların bir arada sunulduğu bu ürünler de seçmenin ne kadar çok duyu organına mesaj gönderilirse, etki o kadar çok olabilmektedir. $\mathrm{Bu}$ anlamda, görsellerin işitsel unsurlarla bir araya getirilerek sunulduğu siyasal iletişim videoları istenilen etkinin oluşturulmasında en çok başvurulan siyasal iletişim ürünleri arasında yer aldığı ifade edilebilir.

Teknolojinin ve dijitalleşmenin iletişime olan etkisi gün geçtikçe artmaktadır. Bu durumun siyasal iletişimde de bir dönüşüme sebep olduğu Lilleker tarafindan ifade edilmektedir. Siyasal iletişimde yaşanan bu dönüşümün eşzamanlı olarak birbiriyle bağlantılı "profesyonelleşme, medyatizasyon ve pazarlama" olarak isimlendirilen üç süreçten geçtiği ifade edilmektedir. Bu süreçlerin, siyasal iletişimcilerin stratejilerini ve taktiklerini şekillendirdiği ve kamunun güven, bağlılık ve katılım düzeylerini temelden etkilediği ileri sürülmektedir. Siyasal iletişimin profesyonelleştirilmesi, siyasetin kamuya ulaşmak için iletişimin yeni biçim ve tarzlarına, yeni iletişim araçlarına adapte olma biçimini açılar. Profesyonelleşmenin medya tarafından yönlendirildiği ve iletişimin medyanın biçimlerine adapte olduğu tartışılmaktadır. İnternetin siyasal iletişim için birincil araç olarak televizyona karşı rekabet ediyor olmasıyla kendimizi bugün hipermedya çă̆ında buluyoruz. Medyatizasyon ise siyasal iletişimcilerin medyada haber yayın süresinde yer alabilmek için gazetecilerin ve editörlerin biçim düzenlerine ve çalışma pratiklerine uyum sağlaması olarak ifade edilmektedir. Siyasi pazarlama literatürü alanındaki uzmanlar, politikanın, mesajların ve sloganların ve iletişim araçlarının tasarımı açısından, pazar olarak gücü elinde bulunduran tüketici veya izleyici kitlesinin olduğunu öne sürmektedir. Pazarlama ise kamunun ve siyaset tüketicisinin (seçmenin) taleplerine uyum sağlamak olarak ifade edilmektedir (Lilleker, 2014: 19).

Siyasal iletişimde internetin kullanılması siyasilere ve siyasi kurumlara özgürlük, hızlılık, kolaylık ve diğer iletişim kanalları ile etkileşim şeklinde olumlu özellikleriyle yeni olanaklar sağlamaktadır. Zaman ve mekân sınırlaması olmadan verilmek istenen mesajlar medyanın sınırlandırmasına takılmadan ve çarpıtılmadan verilebilmekte, diğer medya araçlarına göre mesajların içeriğinde kolayca ve hızlıca güncelleme yapılabilmekte ve mesajlar daha hızlı paylaşılabilmektedir. Ayrıca internet ve yeni medya ortamlarında siyasal aktörlerin ve kurumların daha önceleri ürettikleri yüz yüze, yazıll, sözlü ya da görsel tüm medyada paylaşılmış olan siyasal içeriklerin tekrar üretilmesi ve yaygınlaştırılması imkânı vardır (Aziz, 2011: 69-70). Özellikle sosyal medya liderlerin kamuoyunu etkileme ve ikna etmede önemli bir siyasal iletişim aracı olarak kullanılmaktadır (Sayar ve Duğan, 2017: 311).

Doğru kullanıldığı takdirde, internetin çok fazla görünürlük sağlayabileceği, katılımı teşvik edebileceği ve uzlaşma oluşturmaya katkıda bulunabileceği, böylece bir tarafın veya adayın aldığı oy sayısını arttırabileceği ifade edilmektedir (Giansante, 2015: 9).

Çoğunlukla doğrudan olduğu ifade edilen çevrimiçi siyasal iletişimin aracılık yapabileceği ya da kendi içinde aracı olabileceği ifade edilmektedir. Örneğin, bir parti bir video oluşturarak onu YouTube hesabına yükleyebilir ve bu videoya insanlar yorum yapabilir ya da videoyu paylaşabilirler. Çevrimiçi tüketim için üretilen bu videolar ana haber bültenlerinde yer alıp, gazeteciler tarafindan yorumlanabileceği gibi, çevrimiçi kullanıcılar tarafından çokça destek görebilir ya da şiddetli şekilde olumsuz karşılık da bulabilir (Lilleker, 2014: 38). Bu bağlamda YouTube 
üzerinde paylaşılan siyasal iletişim videolarının oldukça önemli olduğu ifade edilebilir. Ancak paylaşılan videoların seçmen kitle üzerinde olumlu etkilerinin olabileceği gibi, muhaliflerin de sert yorumları ya da videoları muhalif olmak adına çeşitli amaçlarla internet ortamında yayabilecekleri unutulmamalidir.

\section{Yöntem}

Çevrimiçi iletişim bireylerin, kurumların ve şirketlerin etkileşimini görünür kılar ve bu görünenler kendi başına veri olarak değer bulur. Çevrimiçi verilerle çalışmak büyük bir zorluk olarak algılanmaktadır: "Sosyal medya metodolojileri çevrimiçi medyayı analiz etmeye hazır değildir. Çevrimiçi medya üzerinde çalışılacaksa yeni ya da değişikliğe uğratılmış yöntemler gereklidir (Keyling ve Jünger, 2016: 183). Bu sebeple görünene odaklanan bir yöntem olarak bu çalışmada göstergebilim kullanılarak çevrimiçi ortamda paylaşılan videoların değerlendirilmesi amaçlanmıştır. Çünkü siyasal kampanyalar hakkında yapılan araştırmalarda kampanya boyunca siyasi kurum ve kişiler tarafindan siyasal iletişim amaçlı üretilen görseller ayrı bir gözle incelenmekte ve göstergebilimsel olarak çözümlenmektedir (Karakoç ve Taydaş, 2016: 253).

Göstergebilimin temel ilgi odağını göstergeler oluşturur. Göstergelerin ve bunların çalışma biçimlerinin araştırılması göstergebilim olarak isimlendirilir. Göstergebilimde okunacak yani yorumlanacak olan metinde (bir resim, bir fotoğraf vb.) okuyucunun rolü oldukça önemlidir. Çünkü metnin anlamlandırılmasında okurun kendi deneyimlerinin, tutumlarının ve duygularının doğrudan katkısı vardır. Bir gösterge, kendi dışında başka bir şeye göndermede bulunan, duyularla kavranabilir fiziksel bir şeydir ve kullanıcılar tarafindan bir gösterge olarak kabul görmesi ise o şeyin bir gösterge olarak var olmasını sağlar (Fiske, 2017: 122-123). Gösteren ve gösterilen olmak üzere iki elemanın toplamından gösterge oluşmaktadır. Gösteren imgeler topluluğu olarak ifade edilebilir. Gösteren kapsamında değerlendirilen imgelerin ardındaki anlam ve kavramlar kümesi gösterilene işaret etmektedir (Ertan ve Sancarc1, 2017: 32-34).

$\mathrm{Bu}$ çalışmada da incelenen görseller gösterge, gösteren ve gösterilen boyutunda ele alınacaktır. Çalışmada incelenen videolara AK Parti'nin kurumsal YouTube hesabı üzerinden ulaşılmıştır (www.youtube.com/akparti). İncelenen videoların seçiminde nitel araştırmalarda tercih edilen amaçlı örnekleme yöntemi kullanılmıştır (İslamoğlu ve Alnıçık, 2014: 212). Nitel araştırmalarda örneklemin “temsil edicilik” özelliği yerine “özgünlüğü” önemli görülmektedir. $\mathrm{Bu}$ sebeple nitel araştırmalarda özgünlüğü artırmak için amaçlı ve kontrollü örnekleme teknikleri daha çok tercih edilmektedir (Yeşil, 2014: 64). Bu çalışma için seçilen videolar "tüm kalbimle evet" başlığında YouTube üzerinden paylaşılan 13 video ile sınırlandırılmıştır.

$\mathrm{Bu}$ çalışma kapsamında cevap aranacak araştırma soruları ise aşağıda şekildedir.

(i) AK Parti videolarla hangi seçmen kitlesine ulaşmak istemektedir?

(ii) AK Parti'nin videolarda kullandığı sloganlar ile görseller uyumlu mudur? (iii) AK Parti videolarda milli niteliklere yer vermiş midir?

(iv) AK Parti videolarda manevi nitelikli görsellere yer vermiş midir?

(v) AK Parti videolarda yerel nitelikli görsellere yer vermiş midir?

(vi) AK Parti videolarda eğitim nitelikli görsellere yer vermiş midir?

(vii) AK Parti videolarda ekonomik nitelikli görsellere yer vermiş midir?

(viii) AK Parti videolarda toplumsal cinsiyet bağlamında görsellere yer vermiş midir?

\section{Bulgular ve Yorum}

$\mathrm{Bu}$ çalışma kapsamında Adalet ve Kalkınma Partisi'nin YouTube hesabında yayınladığı "Tüm Kalbimle Evet” isimli 13 videosu değerlendirilmiştir. Araştırmanın soruları videolardaki görsellere göre yanıtlanmaya çalışılmıştır. $\mathrm{Bu}$ anlamda araştırma sorularına yanıt aranırken Türkiye'nin 2017 yılındaki ekonomik, sosyal, kültürel ve politik arka planı ise göz önünde bulundurularak görsellerin vermek istediği mesajlar gösteren - gösterilen ilişkisi ile incelenmiştir. $\mathrm{Bu}$ çalışmada incelenen veriler 15 Temmuz 2016 Darbe Girişiminin neticesinde gelişen süreçte anayasa değişikliğine yönelik alınan halk oylaması kararının ardından siyasi kurumlar tarafından üretilen siyasal iletişim videolarının içeriğini incelemesi bakımından önemli görülmektedir. Çünkü 15 Temmuz 2016 Darbe Girişimi ile Türk milletinin her ferdi milli bir birliktelik içerisinde darbeye karşı birleşmiş ve direnmiştir. Halkın bu birlikteliği siyaset kurumlarının da seçim stratejilerine nasıl yansıdığ sorusunu sordurmuştur.

Yaşanan Darbe Girişimi sürecinde milletin manevi birlikteliği de oldukça dikkat çekmiştir. Darbe girişiminin olduğu saatlerde Diyanet İşleri Başkanlığınca tüm camilerden salaların okutulması, halkın kendi imkân ve araçlarıyla organize olarak, özellikle saldırıların olduğu semtlere giderek tüm silahlı darbecilere karşı gösterdikleri direniş ve daha sonraki günlerde halkın meydanlarda dualar etmeleri halkın böylesi bir darbe girişimine karşı olan manevi yönünü göstermektedir denilebilir. Halkın direnişi kentten köye kadar Türkiye'nin tüm yerleşim yerlerinde yaşayan yurttaşlarca günlerce tutulan nöbetlere de yansımıştır.

Darbeler ve darbe girişimleri ülkelerin ekonomisinde büyük kriz oluşturduğu da genel kabul gören bir durumdur. 15 Temmuz darbe Girişiminden sonra da ekonomi alanında darbe girişiminin etkileri olmuştur. Bu duruma çalışmasında dikkat çeken Karagöl (2016: 50), kredi derecelendirme kuruluşları tarafından verilen notların düşürülmesini ve döviz kurunun yükselmesini darbe girişiminin ekonomik maliyetleri arasında siralamaktadır. $\mathrm{Bu}$ referandum kampanyasında 15 Temmuz Darbe Girişimi ardından oluşan sonuçlar siyasi partilerce geliştirilecek olan siyasal iletişim diline etki etmiştir. Bu sonuçlardan bazılarını Alkan (2016: 267) 15 Temmuz Darbe Girişiminin sonuçları üzerine yaptığı çalışmada, "Devletin ve her kesimden siyasetin devşirmeci anlayış ve mekanizmaları terk etmeleridir. Fırsat eşitliğine dayanan ve liyakati esas alan bir kamu hizmeti anlayışının yapılandırılması bu açıdan önem taşımaktadır. Ĕ̈itim sisteminin firsat eşitliğini hayata geçirecek şekilde 
yeniden ele alınması, yalnızca halka güvenilmesi ve patronaja dayalı tüm yolların tıkanması zorunluluğu 15 Temmuz'un en önemli sonuçlarından biridir." değerlendirmesinde bulunmuştur.

$\mathrm{Bu}$ yönüyle düşünüldüğünde 15 Temmuz Darbe Girişimi sonrasında ortaya çıkan bir referandum sürecinde, siyasi kurumlar halkın desteğini alabilmek için siyaset, ekonomi, kültür ve sosyal tüm alanlarda tüm kesimleri kucaklayıcı net bir iletişim dilini gerçekleştirmeleri zorunluluğu ortaya çıkmıştır. Ayrıca siyasi kurumların halk ile arada engel olabilecek her bir kurum ve kişinin ortadan kaldırılması hususunda gerekli projeleri oluşturması ve açık bir siyasal iletişim diliyle bunları anlatmasını gerekli kılmıştır. İşte böylesi bir arka planın olduğu ortamda ortaya konan siyasal iletişim videolarında halkla kurulmak istenen iletişimde hangi unsurların dikkate alındığının incelenmesi bu çalışmada değerli görülmüştür.

$\mathrm{Bu}$ anlamda referandum kampanyası döneminde siyasi partilerin seçmen kitlesine yönelik ürettiği siyasal iletişim mesajlarında milli, manevi, yerel, eğitim, ekonomik ve toplumsal cinsiyet bağlamında hangi içeriklerin üretildiği bilimsel merak konusu olmuştur. AK Parti özelinde halka verilmek istenen mesajların videolardaki görseller aracılığıyla nasıl biçimlendirildiği değerlendirilmeye çalışılmıştır.

Tüm partiler için seçmen kitlenin her birinin değerli olduğu ve bunu göstermek isteyen siyasi partilerin mesajlarında bunu gösteren unsurlara yer verdiği bilinmektedir. İncelenen videolardaki görsellerde kadın, erkek, yaşlı, genç, çocuk, kentli, köylü, çalışan, çalışmayan halkın her kesiminden bireylerin görsellerde yer aldığı değerlendirilmiştir. Bu bakımdan AK Parti'nin cinsiyet ayrımı yapmadan hemen her yaştan ve çeşitli meslek gurubundan, Türkiye'nin farklı şehirlerinden tüm seçmene ulaşmak istediği değerlendirilmiştir.

AK Parti'nin videolarda kullandığ 1 görseller ile sloganların uyumlu olup olmadığına yönelik incelemenin bulguları Tablo 1'de gösterilmektedir.

Tablo 1. Görsel ve Slogan Uyumu

\begin{tabular}{ll}
\hline Görsel & Slogan \\
\hline Yaşlı vatandaşlar & Torunlarım için evet \\
\hline Esnaf ve sanayi çalışanları & $\begin{array}{l}\text { "Gürçlü ekonomi, büyük } \\
\text { "Dahina çok iş için" } \\
\text { "Daha çok yatırım için" } \\
\text { "Ekonominin büyümesi için" }\end{array}$ \\
\hline Türk bayrağı & "Milletimiz için" \\
& "Bayrağımı için" \\
& "Şehitlerimiz için" \\
& "Tarihimiz için"
\end{tabular}

Tablo 1 incelendiğinde, kullanılan bazı sloganlar ile görsellerin uyum içerisinde tasarlandığı ve böyle bir tasarım ile seçmenin etkilenmek istendiği ifade edilebilir. Ancak videolardaki tüm görsellerin sloganlarla uyumlu olarak tasarlanması videolar ile amaçlanan siyasal iletişimin etkisini artırabilirdi.

$\mathrm{Bu}$ çalışmada sınıflandırılmaya tabi tutulan görseller yorumlanırken her bir görsel ayrı ayrı değil genel anlamda verilmek istenen ortak mesajlar bağlamında değerlendirilmiştir.

\section{- Milli nitelikli görseller}

Şekil 1. Videolarda Yer Verilen Milli Nitelikler

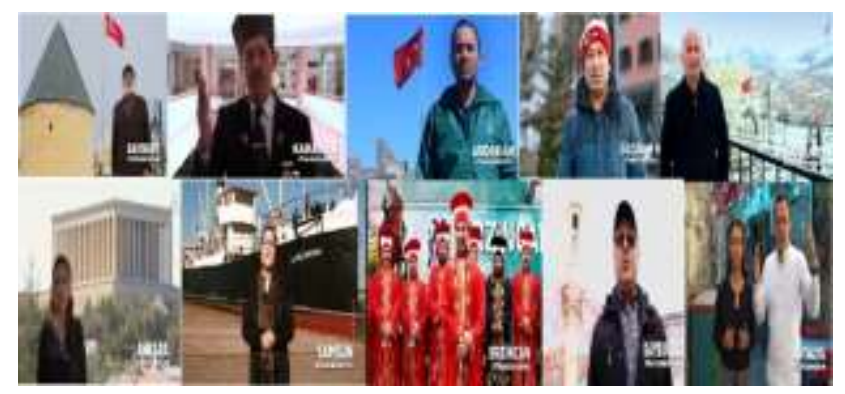

Gösterge: 2017 Referandumu AK Parti “Tüm Kalbimle Evet" YouTube Videoları Görselleri

Gösterenler: Türk bayrağı, Milli değerlerle özdeşleşen kıyafetler, yapılar ve unsurlar, kadın erkek, genç yaşlı bireyler.

Gösterilenler: İncelenen görsellerde Türk bayrağına sıklıkla yer verilmesi, bayrağın ülkenin tüm bireylerini birleştirici olan özelliğini ifade etmektedir. Yaşı bireylerin varlığı Türkiye Cumhuriyetinin köklerinin tarihteki derinliklerine, genç bireylerin varlığı genç ve güçlü bir devlet kavramına çağrışım yapmaktadır. Kadınların temsili düşünüldüğünde; Bandırma Vapuru önünde yer verilen kadının Cumhuriyetin temellerinde ve İstiklal mücadelesinin kazanılmasında kurucu unsur olarak kadının önemli bir rolü ve yeri olduğu mesajı verilmektedir. Anıtkabir önünde genç bir kadınla da Türkiye Cumhuriyetinin kurucusu olarak Mustafa Kemal Atatürk'ün bu toprakları Türklere tekrar yurt yapan kurucu devlet başkanı özelliği vurgulanmıştır. Kuvâ-yi Milliye kıyafetli yaşlı bir erkek görseliyle, görselin taşıdığı anlam ile özdeş olarak birlik ve beraberlik kavramları üzerinden seçmene mesaj verilmiştir. Mehteran görseliyle, AK Partinin gelenek ve göreneklerine bağlı ve mehteranın akla getirdiği davul, bayrak ve tuğ ile de milli hâkimiyet ve bağımsızlık kavramlarına önem veren bir parti olduğu mesajı verilmiştir.

\section{- Manevi nitelikli görseller}

Şekil 2. Videolarda Yer Verilen Manevi Nitelikler

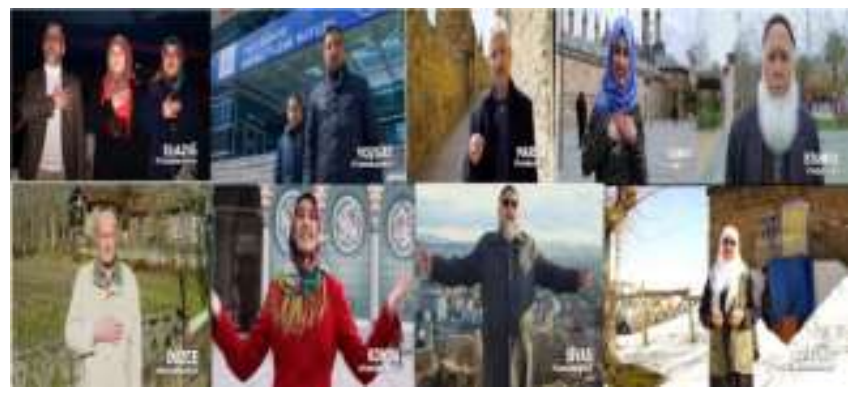

Gösterge: 2017 Referandumu AK Parti “Tüm Kalbimle Evet" YouTube Videoları Görselleri

Gösterenler: Yaşlı kadın ve erkekler, baba ve kızı, genç kadın ve erkekler, aile kavramına çağrışım yapan unsurlar, manevi anlam taşıyan yapılar, manevi çağrışımlar yapan beden dili unsurlar1. 
Gösterilenler: Paylaşılan görsellerden AK Partinin toplumun temel yapısı olan aileye, yaşlılara ve gençlere değer veren bir parti olduğu mesajı verilmiştir. Ayrıca yaşlıların videolarda kullandıkları "Torunlarım İçin Evet" sloganı ile yetişkinlerin verecekleri oyun manevi değerine dikkat çekilerek, seçmenin sandığa gitmesinin neden önemli olduğu mesajı verilmiştir. Bir camiinin önünde kapalı bir kadının ellerini açarak "birlik için, dirlik için" sloganını kullanması ve Mevlana Türbesi önünde genç bir kadının ellerini kalbine birleştirerek Hz. Mevlana'nın hoşgörüsü ile herkese olan "gel” çağrısını hatırlatması bakımından AK Partinin toplumun tüm kesimleriyle bütünleşik bir parti olmak istediği mesajı verilmiştir.

\section{- Yerel nitelikli görseller}

Şekil 3. Videolarda Yer Verilen Yerel Nitelikler

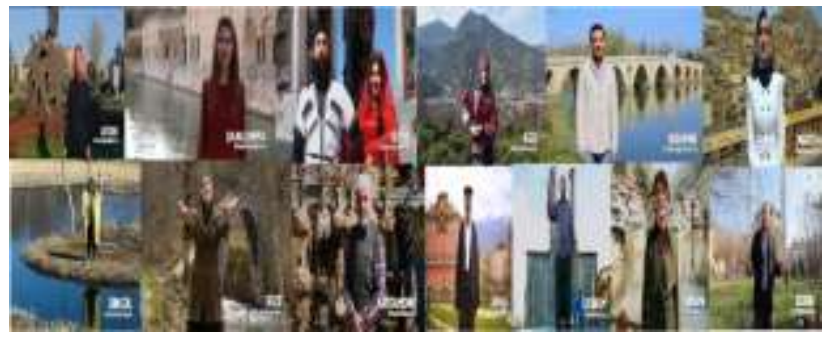

Gösterge: 2017 Referandumu AK Parti "Tüm Kalbimle Evet" YouTube Videoları Görselleri

Gösterenler: Kentle özdeşleşen tarihi dokular, anıt heykeller, köprüler, dini yapılar, kültürel kıyafetler, tarım ürünleri, yaşlı, genç, kadın ve erkek bireyler.

Gösterilenler: İncelenen videolarda Türkiye'deki tüm kentlerin isimlerine ve o kentlerin bazılarının ön plana çıkan yerel özelliklerine yer verilmiştir. Böylece AK Parti Türkiye'nin tüm kentlerindeki seçmenine ayrı ayrı değer verdiği mesajını vermiştir. Görsellerde yer verilen farklı yerel kıyafetlerle, AK Parti farklılıkları zenginlik gördüğü mesajını vermiştir. Bereket, bolluk ve barışın simgelerinden olan incir heykeli önünde genç bir kadın görseli üzerinden, AK Parti barışa ve ekonomik kalkınmaya yönelik bir mesaj vermiştir. Şanlıurfa Balıklıgöl görseliyle, Anadolu'nun tüm bölgelerinin tarihte olduğu gibi günümüzde önemli yerleşim yerleri arasındaki olduğu ve her bir yerel unsurun değerli görüldüğü mesajı seçmene verilmiştir. Rizeli kadınların temsil edildiği görsellerle Karadeniz’in heyecanlı ve neşeli insanına bir çağrışım yapıldığı ve AK Partinin de vatandaşındaki bu duygusal özellikleri partisiyle özdeşleştirdiği mesajı verilmiştir. Bingöl'deki çoban ve Kastamonu'daki sarımsakların yer aldığı görselle üretime küçük büyük katk1 sağlayan tüm kentlerin ülke kalkınmasındaki yerinin parti için değerli olduğu mesajı verilmiştir.

\section{- Eğitim nitelikli görseller}

Şekil 4. Videolarda Yer Verilen Eğitim Nitelikleri

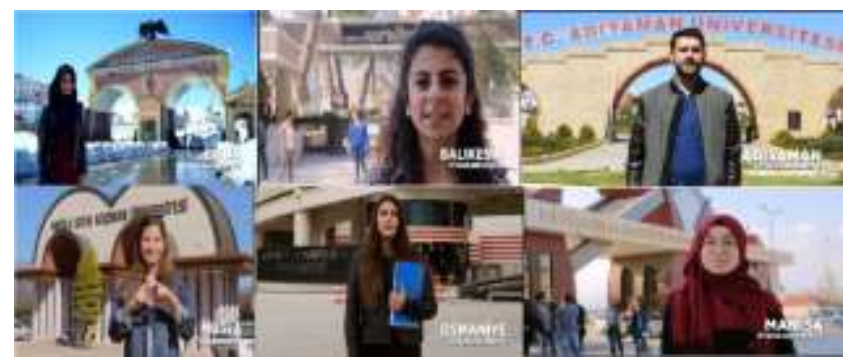

Gösterge: 2017 Referandumu AK Parti “Tüm Kalbimle Evet" YouTube Videoları Görselleri

Gösterenler: Üniversite kampüs girişlerinde tebessüm eden kadın ve erkek üniversiteli öğrenciler.

Gösterilenler: Üniversite kampüslerinin önünde gençlerin bulunduğu görseller ile AK Parti'nin yükseköğrenimin ve bilimin önemine değer verdiği mesajı verilmiştir. Özellikle bu görsellerle genç seçmene mesaj verilmiştir. Ayrıca eğitim görsellerinde çoğunlukla kadın öğrencilerin tercih edilmiş olması, AK Partinin, kadınların yükseköğrenim görerek toplumsal hayatın her alanında daha etkin olmasını isteyen bir parti olduğu mesajı verilmiştir. Yükseköğrenim hayatı özgürlük ve sosyal çevre çağrışımları bakımından değerlendirildiğinde, AK Parti'nin gençlerin özellikle kadın öğrencilerin yükseköğrenimle daha özgür bireyler olabilmelerini ve sosyal hayatın içinde daha çok yer alabilmelerine önem verdiği mesajı verilmiştir. Görsellerde Anadolu'daki üniversitelerin yer alması ise artık Anadolu'daki üniversitelerinde İstanbul, İzmir ve Ankara gibi şehirlerdeki üniversitelerle rekabet edebilen kalitenin olduğu mesajı verilmiştir.

\section{- Ekonomik nitelikli görseller}

Şekil 5. Videolarda Yer Verilen Ekonomik Nitelikler

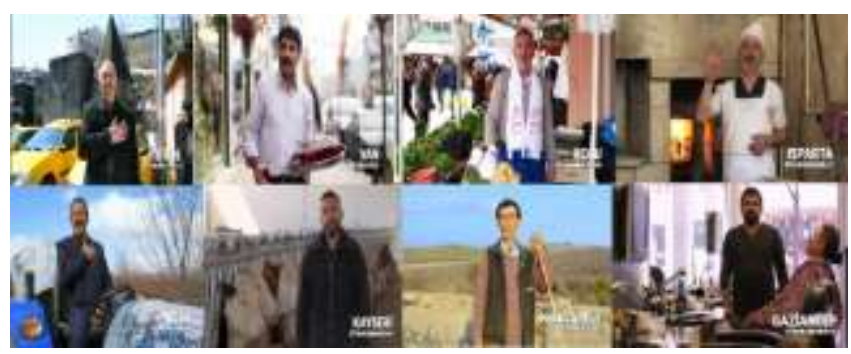

Gösterge: 2017 Referandumu AK Parti “Tüm Kalbimle Evet" YouTube Videoları Görselleri

Gösterenler: Tarım, hayvancılık, gıda ve diğer meslek gruplarından çalışan erkek bireyler.

Gösterilenler: Bu göstergede özellikle küçük ölçekli esnafin temsil edildiği görseller ele alınmıştır. Aşağıda Şekil 6'da paylaşılan görsellerde ise sanayi sektöründe çalışanlar ele alınacaktır. Videolarda oldukça sık yer verilen ekonomik görsellerle, AK Partinin referandumda seçmenden oy isterken partinin şimdiye kadar ortaya koyduğu ekonomi politikalarını hatırlatma arayışının yansıması olarak değerlendirilmiştir. Görsellerde yer alan farklı sektörlerden esnafın: "Büyük Türkiye için"; "Güçlü ekonomi, büyük Türkiye için"; "Daha çok iş için”; "Güçlü bir Türkiye için”; 
sloganlarını kullanmaları, AK Partinin esnafının destekçisi bir parti olduğu mesajını seçmene vermiştir. Böylece AK Parti esnaf seçmenin verecekleri oyların yönünü etkilemek istemiştir.

Şekil 6. Videolarda Yer Verilen Ekonomik Nitelikler

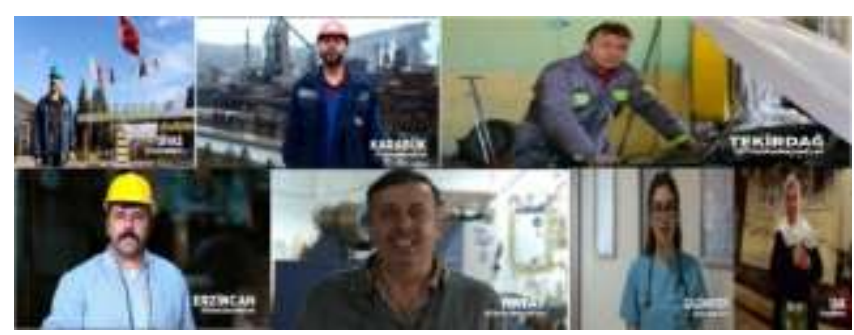

Gösterge: 2017 Referandumu AK Parti “Tüm Kalbimle Evet" YouTube Videoları Görselleri

Gösterenler: Sanayi sektörünün çeşitli alanlarında çalışan erkek bireyler ve çalışma hayatında temsil edilen yaşlı ve genç kadınlar.

Gösterilenler: Şekil 6'da incelenen görseller daha çok sanayi çalışanlarını kapsamaktadır. AK Parti, "Daha Çok Yatırım”; "Ekonominin Büyümesi İçin"; "Gelişen Türkiye İçin"; "Üretimde istikrar için" sloganlarını kuran sanayi çalışanları üzerinden, sanayi üretimine yönelik parti politikaları ve yatırımları hakkında seçmenine mesaj vermek istemiştir. Ayrıca çalışma hayatında kadının varıı̆ını temsili bakımından da kadın hekim ve halı dokuyan Türk kadına görsellerde yer verilmiştir. Böylece AK Parti çalışma hayatının her alanında kadının varlığını önemsediği mesajı vermiştir.

\section{- Toplumsal cinsiyet nitelikli görseller}

Şekil 7. Videolarda Yer Verilen Toplumsal Cinsiyet Nitelikleri

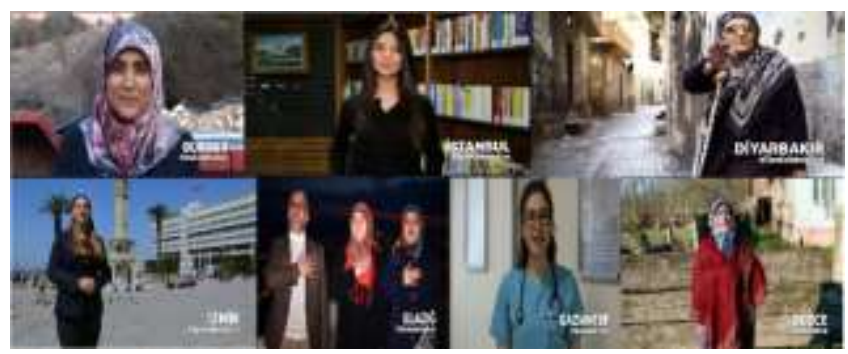

Gösterge: 2017 Referandumu AK Parti “Tüm Kalbimle Evet" YouTube Videoları Görselleri

Gösterenler: Tarımda çalışan, eğitim gören, iş hayatının içinde, aile kurumunda, kentte ve köyde yaşayan genç ve yaşlı kadın bireyler.

Gösterilenler: Toplumsal cinsiyet bağlamında değerlendirilen görsellerde, AK Partinin toplumun her kesiminden kadını hem aile hem de çalışma hayatında ki rolü ile kadınları değerli gördüğü mesajını vermiştir. Türk kadınının kırsalda da kentte de tarımdan eğitim ortamlarına kadar iş hayatının herhangi bir sektöründe, bir anne, bir hekim, bir öğretmen veya bir iş kadını olarak her yerde var olduğu gösterilmek istenmiştir. Kadının Türk toplumunda erkekten farklı olmadığı, erkeğin yapacağı tüm iş alanlarında da kadının şüphesiz varlık gösterebileceği ve gösterdiği ifade edilmiştir. Böylece AK Parti kadını çalışan ve üreten bir birey olarak ülkenin ekonomik kalkınmasında önemli gördüğü mesajını vermiştir.

\section{Sonuc}

Sonuç olarak AK Parti kurumsal YouTube hesabını kullanarak, seçmen kitlenin duymasını, görmesini ve hissetmesini istediği mesajları siyasal iletişim amaçlı olarak ürettiği videolar üzerinden vermek istemiştir. Bu noktada YouTube'un siyasal iletişim aracı olarak AK Parti tarafından kullanıldığı ve YouTube'un bir siyasal iletişim ortamı olduğu ifade edilebilir. Günümüzün önemli bir gerçeği haline gelen yeni medya ortamlarının sunduğu firsatlarla, siyasal partilerin seçmeniyle iletişim kurmasında oldukça önemli görüldüğü ve Türk siyasetinin 2017 Referandum sürecinde iletişim amaçlı yeni medyadan yararlandığı bu çalışmanın sonuçlarından biridir.

Genel olarak çalışma sonuçları videolardaki görseller bağlamında değerlendirildiğinde, AK Partinin tüm seçmen kitlesini hedef alan görselleri videolarda kullandığı, görseller ile sloganların bazılarının uyum içerisinde olduğu, videolarda milli, manevi, yerel, eğitim, ekonomik ve toplumsal cinsiyet bağlamında niteliklerin görsellerde yer verildiği değerlendirilmiştir. AK Parti Türk milletinin her ferdinde ortak anlamlara sahip olan milli nitelikli simgelerden bazılarına görsellerde yer vermiştir. Böylece AK Parti'nin milli bir bilince sahip parti olduğu mesajı verilmiştir. Manevi içerikli görseller ile aile kurumunun, yaşlıların, çocukların ve inançların parti için önemli olduğu mesaj1 verilmiştir. Yerel nitelikli görsellerle, tüm kentlerdeki seçmenini tanıyan ve her bir kente ve seçmeni değerli gördüğü mesajı verilmiştir. Eğitim görsellerinde özellikle kadın öğrencilere yer verilmiştir. Böylece AK Partinin kadın seçmenlerine özellikle değer verdiği mesajı verilmiştir. Videolarda ekonomik nitelikli görsellere oldukça yoğun yer verilmiştir. Böylece AK Parti'nin ülke ekonomisine ve ekonomiye katkı sağlayan tüm unsurlara değer verdiği mesajı verilmiştir. Görsellerde kadın kimliği de bilinçli olarak temsil edilmiştir. Böylece kadın seçmeni değerli görüldüğü mesajı verilmiştir.

Özetle, videolarda Türk bayrağının yer verildiği görsellerin oldukça çok tercih edilmesi ve parti bayraklarının görsellerde yer almayışı, 15 Temmuz Darbe Girişimi ve sonrasındaki süreçte Türkiye vatandaşlarına yönelik daha geniş kapsamlı bir iletişim dilinin geliştirilmek istendiği ifade edilebilir. Manevi içerikli olarak değerlendirilen görseller incelendiğinde, "birlik için, dirlik için" sloganını pekiştirmek amacıyla diğer inançlara sahip vatandaşların da parti için önemli görüldüğünün bir ifadesi olarak, o inançların inanç merkezlerine ait görsellere de yer verilebilirdi. İncelenen videolarda her kentin isminin yer verildiği görseller üretilmiştir. Ancak üretilen görsellerde o kentlere ait kentle özdeşleşen yerel unsurların yeteri kadar görsellerde işlenemediği ifade edilmelidir. Seçmenini etkilemesi bakımından kentle özdeş olan unsurların görsellerinin videolarda yer verilmesi daha etkili olabilirdi. Ayrıca 15 Temmuz Darbe Girişiminden sonra her kentin kent meydanlarında Türk halkının günlerce süren meydan nöbetleri de videolarda işlenebilirdi. Referandumun yapıldığ1 süreç düşünüldüğünde, 15 Darbe Girişiminden etkilenen bir ekonominin olduğu çeşitli araştırmacılarla ortaya konmuştur. Böyle bir ortamda yürütülen referandum 
kampanyasında üretilen ve bu çalışmada değerlendirilen videolarda ekonomik unsurlar dikkatli bir şekilde videolarda işlenmiştir. Ancak toplumsal cinsiyet bağlamında araştırmacı tarafından değerlendirilen görsellerin seçmene verilmek istenen mesajlar bağlamında tam ve net olarak bir iletişim dilinin kurgulanamadığı ifade edilmelidir. Kadının parti için değerli olduğu kadın vatandaşların temsil edildiği görsellerle işlenmeye çalışılsa da daha kapsamlı görsellere yer verilmeyişi bir eksiklik olarak değerlendirilmiştir.

İleride yapılacak çalışmalar için, farklı araştırmacılar tarafından incelenecek olan siyasal iletişim videolarında üretilen sloganların söylem analizi ile değerlendirilmesi bu çalışmanın ortaya koyduğu bulgulara farklı bir bakış açısı getirmesi bakımından değerli olacaktır. Ayrıca bu çalışmadan elde edilen bulgular diğer partiler hakkında yapılacak çalışmalarla da karşılaştırılabilir.

\section{Kaynakça}

Alkan, H. (2016). 15 Temmuz'u Anlamak: Parametreler ve Sonuçlar. Bilig, 79, 253-272.

Aziz, A. (2011). Siyasal Iletişim. Ankara: Nobel Yayın Dağıtım.

Ertan, G., \& Sansarc1, E. (2017). Görsel Sanatlarda Anlam ve Algl. İstanbul: Alternatif Yayıncılık.

Fiske, J. (2017). Illetişim Çalışmalarına Giriş. (Çev. Süleyman İrvan). İstanbul: Pharmakon Yayınevi.

Giansante, G. (2015). Online political communication: How to use the web to build consensus and boost participation. Switzerland: Springer International Publishing. https://doi.org/10.1007/978-3-319-17617-8

Gökçe, O. (2013). Iletişim Nasıl Daha İyi Anlar ve Anlaşılırım. Konya: Çizgi Kitabevi Yayınları.

Gürbüz, S., \& Aydın, B. O. (2017). Siyasal kampanyalarda iletişim aracı olarak sosyal medya: 2017 anayasa değişikliği halkoylamasında siyasi liderlerin instagram kullanımları. İçinde: S. Koç Akgül \& B. Küçüksaraç (Ed.), II. Uluslararası Iletişim Bilimi ve Medya Araştırmaları Kongresi Bildiriler Kitabı (s. 533-547). İstanbul: İstanbul Ayvansaray Üniversitesi ve Kocaeli Üniversitesi.

İslamoğlu, A. H., \& Alnıaçık, Ü. (2014). Sosyal Bilimlerde Araştırma Yöntemleri. İstanbul: Beta Yayıncılık.

Karagöl, E. T. (2016). 15 Temmuz darbe Girişimi ve Türkiye Ekonomisi. ADAM Akademi, 6 (2), 37-50.

Karakoç, E., \& Taydaş, O. (2016). Aday İmajı Oluşumunda Lider Fotoğraflarının Önemi: "7 Haziran 2015 Genel Seçimleri”. İçinde: Şükrü Balcı (ed.), 7 Haziran'dan 1 Kasım'a Türkiye'de Siyasal İletişim Uygulamaları, 243280., Konya: Literatürk Academia.

Keyling, T., \& Jünger, J. (2016). Observing Online Content. In: Gerhard Vowe \& Philipp Hen (Eds.), Political Communication in the Online World Theoretical Approaches and Research Design, (s.183-200). Routledge: New York.
Kılıç, E. A. (2013). Seçmen Tercihinde İmaj Faktörü: Siyasal Parti ve Aday İmajı Karşılaştırmasına Yönelik Bir Alan Araştırması. Iletişim Kuram ve Araştırma Dergisi, 36, 46-73.

Lengauer, G., Donges, P., \& Plass, F. (2013). Media Power in Politics. In: Political Communication Cultures in Western Europe: Attitudes of Political Actors and Journalists in Nine Countries. Barbara Pfetsch (Ed.), (s 171-195), Hampshire, UK: Palgrave Macmillan.

Lilleker, D. G. (2014). Political communication and cognition. New York: Palgrave Macmillan.

McNair, B. (2003). An introduction to political communication. London: Routledge Taylor \& Francis.

Özkan, A. (2015). Siyasetin İletişim Odağı Seçim Kampanyaları. İçinde: Siyasal İletişim Yönetimi; Seçim Kampanyasl, Siyasal Reklam ve İletişim Stratejileri. Abdullah Özkan (Ed.). Konya: Eğitim Yayınevi.

Rawnsley, G. D. (2005). Political Communication and Democracy. Hampshire: Palgrave Macmillan.

Ruddock, A. (2000). Understanding audiences: Theory and method. London: Sage Publications.

Sayar, T. E., \& Duğan, Ö. (2017). Liderlerin Kriz Dönemlerinde Sosyal Medya Kullanımı: Recep Tayyip Erdoğan Örneği. İletişim ve Edebiyat Araştırmalart Dergisi, 15, 303-314.

Weimann, G., \& Brosius, H. (2016). A New Agenda for Agenda-Setting Research in the Digital Era. In: Gerhard Vowe \&Philipp Hen (Eds.), Political Communication in the Online World Theoretical Approaches and Research Design, (s.26-44). New York: Routledge.

Yeşil, R. (2014). Nicel ve Nitel Araştırma Yöntemleri. İçinde: Bilimsel Araştırma Yöntemleri. Remzi Y. Kıncal (Ed.). Ankara: Nobel.

YouTube (2017). AK Parti. (Erişim: 10/10/2017), https://www.youtube.com/akparti 